\title{
Prairie Restoration Effects on Near-Surface Soil Nutrient Changes Over Time in the Ozark Highlands Region of Northwest Arkansas
}

\author{
Kristofor R. Brye, Faith Cordes, Marya McKee \\ Department of Crop, Soil, and Environmental Sciences, University of Arkansas, Fayetteville, USA \\ Email:kbrye@uark.edu,flcordes@uark.edu,marya.mckee@gmail.com
}

How to cite this paper: Brye, K.R., Cordes, F. and McKee, M. (2020) Prairie Restoration Effects on Near-Surface Soil Nutrient Changes Over Time in the Ozark Highlands Region of Northwest Arkansas. Natural Resources, 11, 351-364.

https://doi.org/10.4236/nr.2020.118020

Received: July 11, 2020

Accepted: August 23, 2020

Published: August 26, 2020

Copyright ( 2020 by author(s) and Scientific Research Publishing Inc. This work is licensed under the Creative Commons Attribution International License (CC BY 4.0).

http://creativecommons.org/licenses/by/4.0/ (c) (i) Open Access

\begin{abstract}
The Ozark Highlands is a unique botanical transition zone where native prairie and forest once co-existed, but conversion to managed agricultural landuse has severely reduced the extent of native tallgrass prairie. Quantifying soil nutrient changes over time can contribute to improved understanding of the importance of soil fertility in prairie restoration success. The objective of this study was to evaluate the effects of prairie ecosystem [i.e., chronosequence of four prairie restorations and a native prairie (NP)] and soil moisture regime (SMR; aquic and udic) on the change in extractable soil nutrients over a 12-yr period from 2005 to 2017 in the Ozark Highlands region of northwest Arkansas. Soil Ca content decreased over time $(P \leq 0.05)$ in the 17-year-old-aquic and NP-udic combinations, which did not differ and averaged $-55.7 \mathrm{~kg} \cdot \mathrm{ha}^{-1} \cdot \mathrm{yr}^{-1}$, but did not change over time in all other ecosystem-SMR combinations. Soil Na content also decreased over time $(P \leq 0.05)$ in the 17-year-old-aquic combination $\left(-0.7 \mathrm{~kg} \cdot \mathrm{ha}^{-1} \cdot \mathrm{yr}^{-1}\right)$, but did not change over time in any of the other ecosystem-SMR combinations. Averaged across SMR, soil $\mathrm{P}$ content decreased over time $(P \leq 0.05)$ in the 17 -year-old restoration $\left(-1.6 \mathrm{~kg} \cdot \mathrm{ha}^{-1} \cdot \mathrm{yr}^{-1}\right)$, while did not change over time in the other three restorations and NP. Soil K, Mg, and Zn content changes over time did not differ $(P>0.05)$ among ecosystem or between SMRs. Soil nutrient changes are manifestations of soil organic matter dynamics over time and contribute to the inherent soil fertility status of an ecosystem, which needs to be balanced for proper ecosystem functioning and restoration success.
\end{abstract}

\section{Keywords}

Chronosequence, Native Prairie, Soil Properties 


\section{Introduction}

Historically, North American grasslands covered approximately 69 million hectares of land, spanning from Saskatchewan, Canada to the border of the United States and Mexico, and ranging from the Rocky Mountains to east of the Mississippi River [1]. The grasslands of the North America once existed as the largest ecosystem of dynamic complexity in the region, where approximately $80 \%$ grass species and $20 \%$ forbs or flowers form the vegetative component [1]. Diversity in soil texture, moisture regime, and other soil physical and chemical properties among North American grasslands gave rise to the prairie ecosystem. Across North America, some regions are not dry enough to be considered deserts, while some regions may be too dry to support the water demands of woody/forest vegetation. These differentiations gave rise to three distinct prairie regions: the shortgrass prairie of the West, the tallgrass prairie of the East, and the midgrass prairies in between [1].

The dense root structure of undisturbed grassland sod provides protection from runoff and erosion by conserving rainfall from increased infiltration and water-holding capacity as a result of increased soil organic matter (SOM) [2]. The tallgrass prairies of the eastern United States benefit from ample water supply, where the $\mathrm{C}_{4}$ grasses, such as big bluestem (Andropogon geradii), switchgrass (Panicum virgatum), and Indiangrass (Sorghastrum nutans), have extensive fibrous root systems that can penetrate the soil to great depths, in turn enriching the soil with nitrogen $(\mathrm{N})$, recycling nutrients to the soil surface, and adding humus to the soil as roots turnover and decay [3]. Porosity increases as the pervasive roots decay and provides new conduits for water, gases, and soil nutrient exchange, making the tallgrass prairie the most productive among the three prairie ecosystems [3]. In the absence of fire, the surface-accumulated organic matter will slowly decompose and will eventually contribute to the SOM. However, the rate of organic matter decomposition is at least partially dictated by the degree of wetness a particular location experiences, which relates to the soil's mapped moisture regime, and by soil $\mathrm{pH}$, which influences overall microbial function and activity responsible for SOM decomposition and soil nutrient supply and retention (i.e., soil $\mathrm{Ca}, \mathrm{Mg}$, and $\mathrm{K}$ ) via the cation exchange capacity (CEC).

Historically, grasslands were also viewed as underproductive and subsequently cultivated by homesteaders of the 1830s due to the deep, black (i.e., organic matter rich) characteristic of tallgrass prairies; consequently, tallgrass prairies have been whittled down to less than $1 \%$ of their original extent [1] [4]. As a result of prior disturbance and manipulation, the North American tallgrass prairie is now considered one of the rarest and most endangered ecosystems on Earth [1]. However, prairie restoration has increased in popularity and interest in recent decades, partly due to aesthetics associated with prairies, but also due to their niche in the environment and ecosystem system services prairies provide. Mlot et al. reported that the soil-enhancing properties of prairie plants in general, not just the grasses alone, act as the foundation upon which to build restoration activities, as plants and soil biota play a major role in successful restoration 
of grasslands to native states [4]. Understanding the dynamic response of soil properties to prairie restoration activities can benefit from the observation of soil property change over time at various points in time after initiation of restoration activities [5]. Even more useful is to track soil property change over time in multiple prairie restorations of varying ages, or a chronosequence, with comparison to soil properties in a relevant native prairie, provided one exists.

Belowground soil properties are also critical to a prairie ecosystem's proper functioning and are even more critical for prairie restorations [6] [7] [8]. Prairie restoration success is site-specific and dependent on numerous factors, such as landuse prior to restoration, the extent of previous management practices affecting the initial condition of the soil, parent material, topography, and soil moisture regime (SMR) [7]. Furthermore, fewer studies have been conducted in prairie restorations in regions somewhat wetter (i.e., udic SMR) than those in the Great Plains, which is dominated by the ustic SMR and even drier aridic SMR in some places.

The Ozark Highlands in northwest Arkansas is a unique region located between the warm, but drier Great Plains region to the west and northwest that supports primarily grassland communities and the warmer, but wetter sub-tropical region to the southeast that supports primarily forest communities [9] [10]. Thus, the Ozark Highlands is a botanical transition zone where native prairie and forest were once mixed [10], but now the native prairie area is mostly absent, where much of the historic native prairie has been converted to managed agricultural landuse [9].

Brye et al. [6] and Brye and Riley [8] evaluated the effects of landuse conversion from managed pastureland to grassland among a chronosequence of prairie restorations (i.e., 3-, 5-, and 26-years old) on soil physiochemical properties compared to a native tallgrass prairie in the Ozark Highlands. However, both studies relied on a single temporal soil sampling in each prairie ecosystem and made inferences about temporal changes through comparison of results across the prairie restorations of varying age, thus neither study could not properly assess soil property change over time, as the same sites had not been sampled more than once. Consequently, McKee et al. [7] summarized results of soil sampling the same sites 12 years after the original soil sampling took place and reported actual changeover-time results, but for only bulk density, $\mathrm{pH}$, and $\mathrm{C}$ and $\mathrm{N}$ related soil properties.

Considering other soil nutrients, released during the decomposition of SOM, also play an important role in proper prairie function and eventual restoration success, characterizing soil nutrient dynamics within prairie restorations in the Ozark Highlands is warranted. The objective of this study was to evaluate the effects of prairie ecosystem (i.e., chronosequence of four prairie restorations and a native prairie) and soil moisture regime (aquic and udic) on the change in extractable soil nutrients over a 12 -yr period from 2005 to 2017 in the Ozark Highlands region of northwest Arkansas. It was hypothesized that the change over time for numerous extractable soil nutrients will be greater in younger than 
in older prairie restorations and the native prairie because an equilibrium will have already been achieved after some time following initiation of restoration activities. It was also hypothesized that, similar to the behavior of soil C, soil nutrients will tend to accumulate more under wet- (i.e., aquic SMR) than moist-soil conditions (i.e., udic SMR).

\section{Materials and Methods}

\subsection{Regional Characteristics}

Similar to recent work by McKee et al. [7], two prairie locations were evaluated in this study, Pea Ridge National Military Park in Garfield, Arkansas and the Searles Prairie in Rogers, Arkansas, both of which are located within the Springfield Plateau section of the Ozark Highlands, major land resource area (MLRA) $116 \mathrm{~A}\left(36^{\circ} \mathrm{N}-38^{\circ} \mathrm{N}\right.$ lat., $91^{\circ} \mathrm{W}-94^{\circ} \mathrm{W}$ long.) [11]. Major land resource area $116 \mathrm{~A}$ resides partly within southern Missouri and northeastern Oklahoma, with 23\% of the area located in northwest/north-central Arkansas [11]. The Springfield Plateau of the Ozark Highlands is approximately 2.1 million hectares of variable landscape and relief, where forested slopes transition into stony valleys and grasslands, some native prairies. Soil parent materials within the area are typically residual limestone, shale, and sandstone, which weathers into a medium- to fine-textured cherty residuum from which shallow to deep Udults and Udalfs develop [11] [12]. Tree species within MLRA 116A include oak (Quercus spp.), hickory (Carya spp.), and shortleaf pine (Pinus echinata), while many of the grasslands of the region are managed as haylands and/or pastures and are dominated by introduced tall fescue (Lolium arundinaceum) [11] [12].

The climate within the Ozark Highlands is humid temperate. The mean annual air temperature is $14.5^{\circ} \mathrm{C}$, while the mean annual precipitation is $116 \mathrm{~cm}$ [13].

\subsection{Site Descriptions}

Since 2005, research has been conducted in five prairie ecosystems, including a chronosequence of four prairie restorations (PR) at the Pea Ridge National Military Park and a native prairie (NP, Searles Prairie) [6] [7]. The two prairie locations, containing the five prairie ecosystems, were targeted for evaluation due to their relatively close proximity to each other and their availability to be accessed for research purposes. Pea Ridge National Military Park encompasses 1740 ha of woodlands, grasslands, and former cultivated agricultural landuse [14]. The National Parks Service incorporated the use of prescribed burning and herbicide application to convert much of the former cultivated agricultural areas to more historic landuse (i.e., tallgrass prairie) that was present during the Civil War [14]. The four tallgrass prairie restorations were established in 1979, 2000, 2001, and 2002, thus, in 2005, these sites were $26,5,4$, and 3 years old, respectively (Figure 1). The historic landuse associated with the three youngest restorations included managed grasslands, primarily tall fescue and Bermudagrass (Cynodon dactylon), that were periodically rotational grazed with 5 to 20 head of cattle per hectare and periodically limed and fertilized with $\mathrm{N}, \mathrm{P}$, and $\mathrm{K}$ for optimal prod- 
uctivity [8]. The restorations range in area from approximately 2 ha in the 1979 restoration) to 11 ha in the 2002 restoration.

Searles Prairie is an approximate 4-ha parcel of a native tallgrass prairie (Figure 1) located approximately $16 \mathrm{~km}$ west of the chronosequence of the prairie restorations at the Pea Ridge National Military Park [15]. The Searles Prairie is a remnant of the once prominent 4047-ha Osage Prairie and has prominent prairie mounds and typical prairie vegetation species, such as big bluestem ( $A n-$ dropogon geradii), little bluestem (Schizachyrium scoparium), and switchgrass (Panicum virgatum) [15].
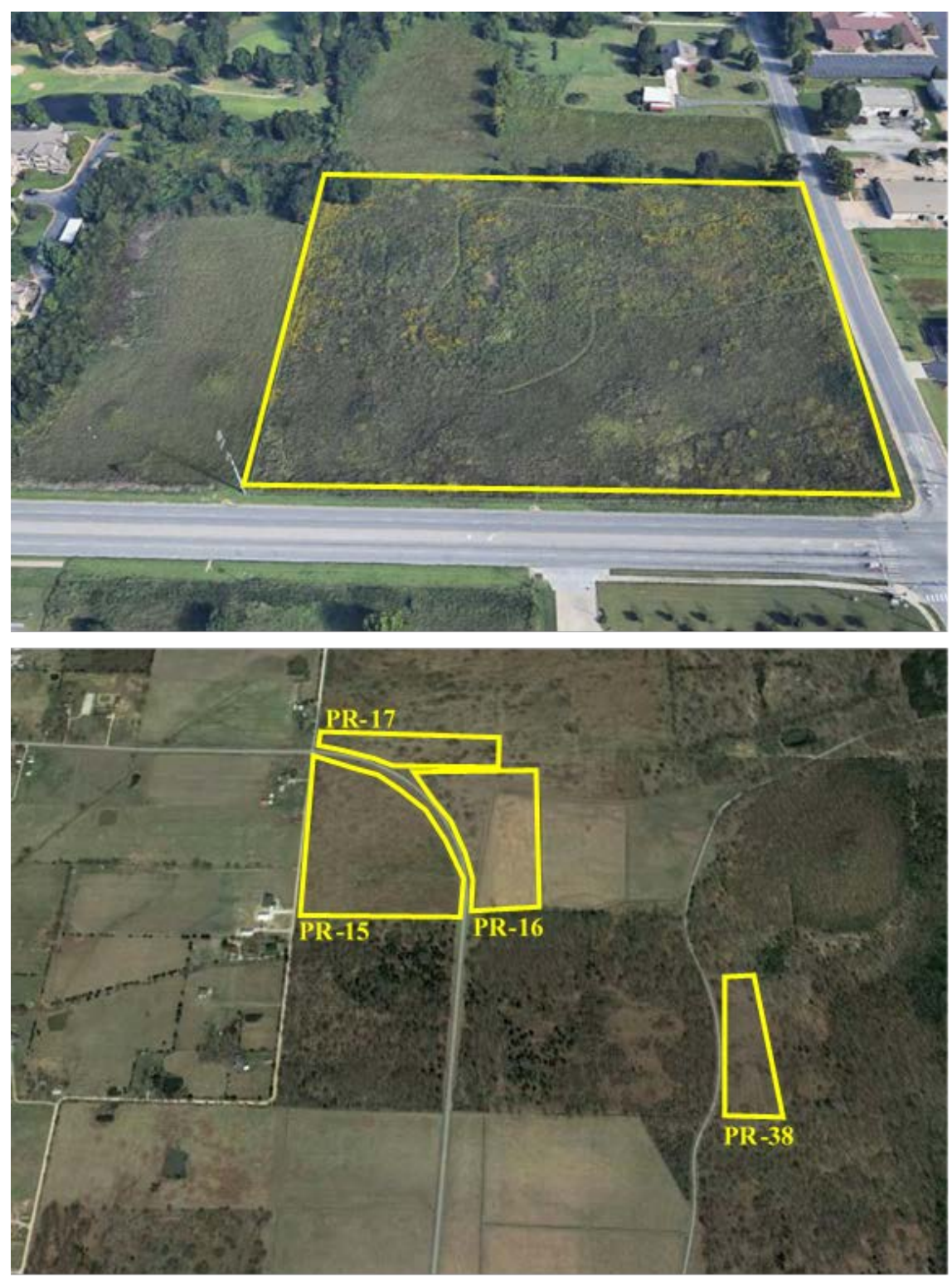

Figure 1. Aerial images of the native tallgrass Searles Prairie (top panel) in Rogers, AR and the chronosequence of prairie restorations (PR, bottom panel) at the Pea Ridge National Military Park near Garfield, AR. In 2017, the 1979, 2000, 2001, and 2002 restorations were 38-, 17-, 16-, and 15-years old. North is in the direction of the top of both panels. 
The soils present throughout the five prairie ecosystems range from sandy loam with $5 \%$ clay to loam with $17 \%$ clay in the top $10 \mathrm{~cm}$ [6] (Table 1). Excluding the oldest restoration (1979) that has only a udic SMR present, the other four prairie restorations and the native prairie have both aquic and udic SMRs present (Table 1) [7].

\subsection{Soil Sampling and Processing}

Following procedures by Brye et al. [6] and McKee et al. [7], five soil samples were manually collected from the top $10 \mathrm{~cm}$ with a slide hammer and a $4.8-\mathrm{cm}$ diameter, stainless steel core chamber at five points along a $60-\mathrm{m}$, geo-referenced, line transect $(0,15,30,45$, and $60 \mathrm{~m})$ in November 2005 in each SMR present in each prairie ecosystem. In January 2017, soil samples were collected again from the same five points along the same $60-\mathrm{m}$ transects in each of the five prairie ecosystems. All soil samples were oven-dried at $70^{\circ} \mathrm{C}$ for 48 hours, weighed to determine bulk density, and crushed to pass through a 2-mm mesh screen for soil chemical analysis.

Sub-samples of soil were analyzed for $\mathrm{P}, \mathrm{K}, \mathrm{Ca}, \mathrm{Mg}, \mathrm{S}, \mathrm{Na}, \mathrm{Fe}, \mathrm{Mn}, \mathrm{Zn}$, and $\mathrm{Cu}$ following extraction in a 1:10 soil mass:extractant-solution-volume ratio [16] and measurement by inductively coupled, argon-plasma spectrometry (Spectro Arcos ICP, Spectro Analytical Instruments, Inc., Kleve, Germany). Using the 10-cm sample depth and measured bulk density, measured elemental concentrations $\left(\mathrm{mg} \cdot \mathrm{kg}^{-1}\right)$ were converted to contents $\left(\mathrm{kg} \cdot \mathrm{ha}^{-1}\right)$ for data analyses and reporting.

Table 1. Summary of land use, restoration age, surface slope, and soil properties in the 0- to 10-cm depth interval for a native tallgrass prairie (Rogers, AR) and a nearby chronosequence of four tallgrass prairie restorations at the Pea Ridge National Military Park (near Garfield, AR) in the Ozark Highlands region of northwest Arkansas.

\begin{tabular}{|c|c|c|c|c|c|c|c|c|}
\hline Land use & $\begin{array}{c}\text { Years of } \\
\text { Restoration }\end{array}$ & Soil Series & $\begin{array}{l}\text { Soil Taxonomic } \\
\text { Description }\end{array}$ & Slope $(\%)^{* *}$ & $\begin{array}{c}\text { Sand } \\
\left(g \cdot g^{-1}\right)^{\star *}\end{array}$ & $\begin{array}{c}\text { Silt } \\
\left(g \cdot g^{-1}\right)^{\star *}\end{array}$ & $\begin{array}{c}\text { Clay } \\
\left(g \cdot g^{-1}\right)^{\star *}\end{array}$ & $\begin{array}{l}\text { Soil Textural } \\
\text { Class }\end{array}$ \\
\hline \multirow[t]{2}{*}{ Native Prairie } & 0 & Jay & Oxiaquic Fragiudalf & $1-3$ & 0.34 & 0.58 & 0.09 & Silt loam \\
\hline & & Cherokee & Typic Albaqualf & $<1$ & 0.40 & 0.48 & 0.12 & Loam \\
\hline \multirow[t]{11}{*}{ Prairie Restoration } & 15 & Peridge $^{\dagger}$ & Typic Paleudalf & $1-3$ & 0.55 & 0.40 & 0.05 & Sandy loam \\
\hline & & Jay & Oxyaquic Fraguidualf & $1-3$ & 0.48 & 0.42 & 0.10 & Loam \\
\hline & & Taloka & Mollic Albaqualf & $<1$ & 0.41 & 0.44 & 0.15 & Loam \\
\hline & 16 & Peridge & Typic Paleudalf & $1-3$ & 0.49 & 0.43 & 0.08 & Loam \\
\hline & & Captina & Typic Fragiudult & $1-3$ & 0.46 & 0.45 & 0.09 & Loam \\
\hline & & Jay & Oxiaquic Fragiudalf & $1-3$ & 0.39 & 0.46 & 0.15 & Loam \\
\hline & & Taloka & Mollic Albaqualf & $<1$ & 0.43 & 0.42 & 0.15 & Loam \\
\hline & 17 & Captina & Typic Fragiudult & $1-3$ & 0.32 & 0.59 & 0.09 & Silt loam \\
\hline & & Taloka & Mollic Albaqualf & $<1$ & 0.45 & 0.38 & 0.17 & Loam \\
\hline & 38 & Peridge & Typic Paleudalf & $1-3$ & 0.54 & 0.36 & 0.10 & Sandy loam \\
\hline & & Captina & Typic Fragiudult & $1-3$ & 0.44 & 0.44 & 0.12 & Loam \\
\hline
\end{tabular}

${ }^{*}$ Years since initial restoration to the date of last soil sampling (i.e., 2017). ${ }^{*}$ Information reported originally in Brye et al. [6]. ${ }^{\dagger}$ Soil series was changed from Cane to Peridge after 2005 [6]. 
Soil bulk density data from the initial soil sampling in 2005 were reported in Brye et al. [6] and in McKee et al. [7] for the 2017 sampling for all four prairie restorations and native prairie. Soil property changes over time were calculated point by point along the transect by subtracting the 2005-measured results from the 2017-measured results and dividing by the fractional time to the nearest day. A negative calculated change represented a decrease, while a positive change represented an increase over time. Soil chemical property results from the initial soil sampling in 2005 were reported in Brye et al. [6] for all four prairie restorations and native prairie.

\subsection{Statistical Analyses}

A two-factor analysis of variance (ANOVA) was performed using the PROC GLIMMIX procedure in SAS (version 9.4, SAS Institute, Inc., Cary, NC) to evaluate the effect of prairie ecosystem (four prairie restorations and the native prairie), SMR (aquic and udic), and their interaction on the change in extractable soil nutrient contents in the top $10 \mathrm{~cm}$ over time. Since the oldest restoration did not have any data for an aquic SMR, the resulting dataset was unbalanced. Consequently, when the interaction term was initially non-significant, statistical analyses were re-conducted removing the interaction term from the model in order to independently evaluate the main effects of ecosystem and SMR. Means were separated by least significant difference, when appropriate, at the 0.05 level for which significance was judged.

\section{Results and Discussion}

With the exception of $\mathrm{K}, \mathrm{Mg}$, and $\mathrm{Zn}$, all other measured extractable soil nutrient content changes over time were affected $(P \leq 0.05)$ by ecosystem and/or SMR (Table 2). Extractable soil $\mathrm{Ca}$ and Na content changes over time differed ( $P$ $\leq 0.05$ ) among ecosystem-SMR combinations (Table 2). Extractable soil Ca content decreased over time $(P \leq 0.05)$ in the 2000 -aquic and NP-udic combinations, which did not differ and averaged $-55.7 \mathrm{~kg} \cdot \mathrm{ha}^{-1} \cdot \mathrm{yr}^{-1}$, while soil Ca content did not change over time in all other ecosystem-SMR combinations (Figure 2). Extractable soil Ca content change over time was more than 10 times lower in the 2000-aquic and NP-udic than in all other ecosystem-SMR combinations, which did not differ from one another, with the exception of that in the 2001-aquic and 2000-udic combinations, which did not differ from that in the udic-NP combination (Figure 2). Extractable soil Ca content changed more over time in the 2000-udic (no change) than in the 2000-aquic (decrease) combination, but changed more in the NP-aquic (no change) than in the NP-udic (decrease) combination, while soil Ca content change over time did not differ between SMRs in the 2001 and 2002 prairie restorations (Figure 2). In the udic SMR, soil Ca content change over time did not differ among any prairie restoration, which was at least numerically greater than the soil Ca content change over time in the NP, and tended to numerically change in the opposite direction of that in the NP with increasing 
restoration age (Figure 2). In contrast, in the aquic SMR, soil Ca content change over time did not differ in the 2001 and 2002 restorations and NP, which were all greater that in the 2000 restoration, and tended to change in the opposite direction of that in the NP with increasing restoration age (Figure 2). Soil Ca content changes over time did not follow clear trends among prairie ecosystems.

Table 2. Analysis of variance summary of the effects of ecosystem, soil moisture regime (SMR), and their interaction on the change in Mehlich-3 extractable soil nutrient [i.e., phosphorus $(\mathrm{P})$, potassium $(\mathrm{K})$, calcium $(\mathrm{Ca})$, magnesium $(\mathrm{Mg})$, sulfur $(\mathrm{S})$, sodium $(\mathrm{Na})$, iron $(\mathrm{Fe})$, manganese $(\mathrm{Mn})$, zinc $(\mathrm{Zn})$, and copper $(\mathrm{Cu})]$ content changes over a 12-year period in an undisturbed native prairie and a chronosequence of four prairie restorations in the Ozark Highlands region of northwest Arkansas.

\begin{tabular}{|c|c|c|c|}
\hline \multirow{2}{*}{ Soil Chemical Property } & Ecosystem & SMR & Ecosystem $\times$ SMR \\
\hline & \multicolumn{3}{|c|}{$P$} \\
\hline $\mathrm{P}$ & 0.02 & 0.85 & 0.26 \\
\hline $\mathrm{K}$ & 0.48 & 0.19 & 0.09 \\
\hline $\mathrm{Ca}$ & 0.13 & 0.77 & $<0.01$ \\
\hline $\mathrm{Mg}$ & 0.51 & 0.09 & 0.10 \\
\hline$S$ & $<0.01$ & $<0.01$ & 0.23 \\
\hline $\mathrm{Na}$ & $<0.01$ & $<0.01$ & 0.05 \\
\hline $\mathrm{Fe}$ & 0.48 & $<0.01$ & 0.10 \\
\hline Mn & $<0.01$ & 0.05 & 0.44 \\
\hline $\mathrm{Zn}$ & 0.10 & 0.89 & 0.71 \\
\hline $\mathrm{Cu}$ & 0.01 & 0.07 & 0.23 \\
\hline
\end{tabular}

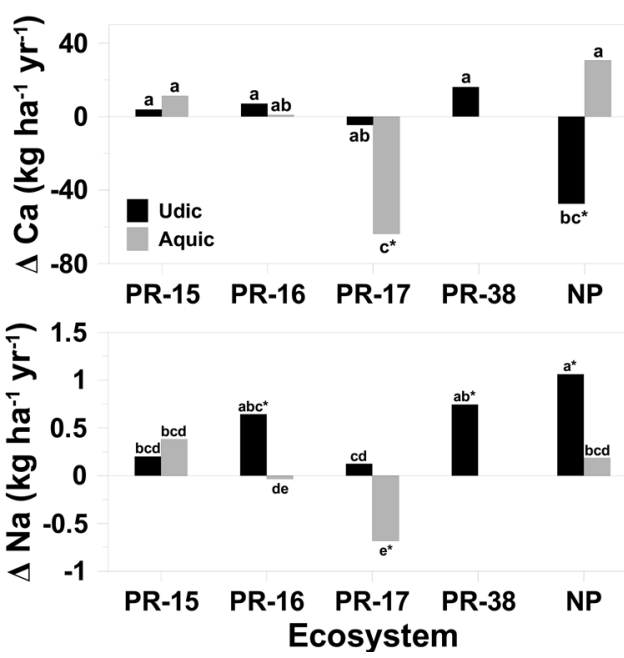

Figure 2. Prairie ecosystem by soil moisture regime effects on the change in extractable soil calcium $(\mathrm{Ca})$ and sodium $(\mathrm{Na})$ in the top $10 \mathrm{~cm}$ over a 12 -year period from 2005 to 2017 among a chronosequence of prairie restorations (PR; 15-, 16-, 17-, and 38-years old in 2017) and a native prairie (NR; Searles Prairie). Means with different letters atop bars on a panel are different at $P \leq 0.05$. Asterisks indicate a significant $(P \leq 0.05)$ change over time from a change of zero. 
Brye et al. [6] reported a nearly six-fold variation in soil Ca content across ecosystems and soil depths, where the greatest soil Ca content was in the 5-yr-old restoration and the lowest was in the 26-yr old restoration. Brye and Riley [8] also reported similar, widely varying soil Ca contents, which differed among prairie ecosystems without a clear temporal trend and reported that the cessation of lime amendments from past agricultural activities had little impact on soil Ca content, which was also corroborated by Brye and Gbur [10].

Extractable soil $\mathrm{Na}$ content increased over time $(P \leq 0.05)$ in the 2001-udic, 1979-udic, and NP-udic combinations, which did not differ and averaged 0.8 $\mathrm{kg} \cdot \mathrm{ha}^{-1} \cdot \mathrm{yr}^{-1}$, and was at least seven times larger than that in the 2001- and 2002-aquic combinations (Figure 2). Similar to $\mathrm{Ca}$, soil $\mathrm{Na}$ content decreased over time $(P \leq 0.05)$ in the 2000 -aquic combination $\left(-0.7 \mathrm{~kg} \cdot \mathrm{ha}^{-1} \cdot \mathrm{yr}^{-1}\right)$, while soil $\mathrm{Na}$ content did not change over time in any other ecosystem-SMR combinations (Figure 2). Extractable soil Na content changed more over time in the 2001-udic and NP-udic (increase) than in the 2001-aquic and NP-aquic (no change) and changed more over time in the 2000-aquic (decrease) than in the 2000-udic (no change) combination, while soil $\mathrm{Na}$ content change did not differ over time between SMRs in 2002 prairie restoration (Figure 2). In the udic SMR, soil Na content change over time was at least 6.6 times greater in the 2002 and 1979 restorations and NP than that in the 2000 restoration and tended to numerically increase over time towards that in the NP with increasing restoration age (Figure 2). In the aquic SMR, soil Na content change over time was greater in the 2002 restoration and NP (no change) than in the 2000 restoration (decrease) and tended to numerically change in the opposite direction of that in the NP with increasing restoration age (Figure 2). Similar to $\mathrm{Ca}$, soil $\mathrm{Na}$ content changes over time did not follow clear trends among prairie ecosystems. Brye et al. [6] and Brye and Riley [8] reported large variation in extractable soil $\mathrm{Na}$ content across prairie restorations, but that, 12 years earlier, extractable soil $\mathrm{Na}$ decreased linearly in the top $10 \mathrm{~cm}$ as restoration age increased, though magnitudes tended towards those lower than that in the native prairie, as interpreted from the single soil sample in the chronosequence of prairie restorations.

Extractable soil $\mathrm{P}, \mathrm{S}, \mathrm{Mn}$, and $\mathrm{Cu}$ content changes over time differed $(P<$ 0.02 ) among prairie ecosystems (Table 2). Averaged across SMR, extractable soil $\mathrm{P}$ content decreased over time $(P \leq 0.05)$ only in the 2000 restoration $(-1.6$ $\left.\mathrm{kg} \cdot \mathrm{ha}^{-1} \cdot \mathrm{yr}^{-1}\right)$, while soil $\mathrm{P}$ content did not change over time in the other three restorations and NP (Table 3 ). Soil $\mathrm{P}$ content change over time tended to numerically change in the opposite direction of that in the NP with increasing restoration age (Table 3 ). Twelve years earlier, soil $\mathrm{P}$ content varied among prairie restorations and was similar among the three youngest restorations, which was greater than that in the oldest restoration and the native prairie [6]. In contrast, soil $\mathrm{P}$ tended towards that in the native prairie as restoration age increased, as interpreted from the single soil sample in the chronosequence of prairie restorations [6]. 
Averaged across SMR, extractable soil S content decreased over time ( $P \leq$ $0.05)$ in the 2002 and 2000 restorations and NP, which did not differ and averaged $-0.5 \mathrm{~kg} \cdot \mathrm{ha}^{-1} \cdot \mathrm{yr}^{-1}$, while soil $\mathrm{S}$ content did not change over time in the 2001 and 1979 restorations (Table 3). Soil S content change over time was at least six times lower in the 2002 and 2000 restorations and NP than that in the 2001 and 1979 restorations (Table 3). In contrast to $\mathrm{P}$, soil S content change over time tended to numerically change in the direction of that in the NP with increasing restoration age (Table 3). Brye et al. [6] and Brye ad Riley [8] also reported soil S decreasing as restoration age increased and in the trajectory of that in the native prairie, as interpreted from the single soil sample in the chronosequence of prairie restorations.

Averaged across SMR, extractable soil Mn content increased over time ( $P \leq$ $0.05)$ in all four prairie restorations, but did not change over time in the NP (Table 3). Soil Mn content change over time was greater in the 2002, 2001, and 1979 restorations, which did not differ, than that in the NP (Table 3). However, soil Mn content change over time in the 2000 restoration was intermediate and similar to that in the 2002 and 2001 restorations and NP (Table 3). Similar to P, soil Mn content change over time tended to numerically change in the opposite direction of that in the NP with increasing restoration age (Table 3). Brye et al. [6] and Brye and Riley [8] both showed an increase in soil Mn content as restoration age increased, tending towards greater magnitudes than that measured in native prairie, as interpreted from the single soil sample in the chronosequence of prairie restorations.

Averaged across SMR, extractable soil $\mathrm{Cu}$ content increased over time ( $P \leq$ $0.05)$ only in the 2001 restoration $\left(0.04 \mathrm{~kg} \cdot \mathrm{ha}^{-1} \cdot \mathrm{yr}^{-1}\right)$ and was greater than that in the other three restorations and NP, which did not change over time (Table 3 ). Similar to $\mathrm{P}$ and $\mathrm{Mn}$, soil $\mathrm{Cu}$ content change over time tended to numerically change in the opposite direction of that in the NP with increasing restoration age (Table 3). Brye et al. [6] concluded soil $\mathrm{Cu}$ in the top $10 \mathrm{~cm}$ increased as restoration age increased in the three youngest prairie restorations and tended towards

Table 3. Summary of mean changes in extractable soil phosphorus (P), sulfur (S), manganese $(\mathrm{Mn})$, and copper $(\mathrm{Cu})$ contents in the top $10 \mathrm{~cm}$ over a 12 -year period among a chronosequence of four prairie restorations (PR; 15, 16, 17, and 38 years old) and an undisturbed native prairie (NP) averaged across soil moisture regimes in the Ozark Highlands region of northwest Arkansas.

\begin{tabular}{|c|c|c|c|c|c|}
\hline \multirow{2}{*}{ Soil Chemical Property } & \multicolumn{5}{|c|}{ Ecosystem } \\
\hline & PR-15 & PR-16 & PR-17 & PR-38 & $\mathrm{NP}$ \\
\hline $\mathrm{P}\left(\mathrm{kg} \cdot \mathrm{ha}^{-1} \cdot \mathrm{yr}^{-1}\right)$ & $-0.06 \mathrm{~b}^{\dagger}$ & $0.53 \mathrm{~b}$ & $-1.59 a^{\star}$ & $0.64 \mathrm{~b}$ & $0.43 \mathrm{~b}$ \\
\hline $\mathrm{S}\left(\mathrm{kg} \cdot \mathrm{ha}^{-1} \cdot \mathrm{yr}^{-1}\right)$ & $-0.36 a b^{*}$ & $-0.01 \mathrm{c}$ & $-0.56 \mathrm{a}^{\star}$ & $-0.05 b c$ & $-0.64 a^{*}$ \\
\hline $\operatorname{Mn}\left(\mathrm{kg} \cdot \mathrm{ha}^{-1} \cdot \mathrm{yr}^{-1}\right)$ & $5.58 \mathrm{ab}^{\star}$ & $4.48 \mathrm{ab}^{*}$ & $2.76 b c^{\star}$ & $6.76 \mathrm{a}^{*}$ & $-0.04 \mathrm{c}$ \\
\hline $\mathrm{Cu}\left(\mathrm{kg} \cdot \mathrm{ha}^{-1} \cdot \mathrm{yr}^{-1}\right)$ & $-0.01 b$ & $0.04 \mathrm{a}^{*}$ & $-0.04 \mathrm{~b}$ & $-0.03 b$ & $-0.04 \mathrm{~b}$ \\
\hline
\end{tabular}

${ }^{\dagger}$ Different letters in a row are difference at $P \leq 0.05 ;{ }^{*}$ Asterisks indicate a significant change over time $(P \leq$ $0.05)$. 
that in the native prairie, while, in contrast, Brye and Riley [8] reported a decrease in soil $\mathrm{Cu}$ as restoration age increased, as interpreted from the single soil sample in the chronosequence of prairie restorations.

Extractable soil $\mathrm{S}, \mathrm{Fe}$, and $\mathrm{Mn}$ content changes over time differed $(P \leq 0.05)$ between SMRs (Table 2). Averaged across prairie ecosystems, extractable soil S content decreased over time $(P \leq 0.05)$ in the aquic SMR, which was 12 times greater than that in the udic SMR, which did not change over time (Table 4). In contrast to soil S, averaged across prairie ecosystems, extractable soil Fe content increased over time $(P \leq 0.05)$ in the udic SMR, which was 3.8 times greater than that in the aquic SMR, which did not change over time (Table 4). Similar to soil $\mathrm{Fe}$, averaged across prairie ecosystems, extractable soil Mn content increased over time $(P \leq 0.05)$ in the udic and aquic SMRs, but the increase in the udic was 1.8 times greater than that in the aquic SMR (Table 4). Twelve years earlier, soil Fe in the top $10 \mathrm{~cm}$ was similar among the three youngest restorations, lowest in the oldest restoration, and decreased as restoration age increased, tending towards magnitudes lower than that measured in native prairie [6]. However, Brye and Riley [8] also reported a general decrease in soil Fe as restoration age increased, but with magnitudes tending towards those in the native prairie, as interpreted from the single soil sample in the chronosequence of prairie restorations.

In contrast to the other measured soil nutrients, extractable soil $\mathrm{K}, \mathrm{Mg}$, and $\mathrm{Zn}$ content changes over time were unaffected by ecosystem or SMR $(P>0.05$; Table 2). Averaged across ecosystem and SMR, extractable soil $\mathrm{K}$ content change over time averaged $1.2 \mathrm{~kg} \cdot \mathrm{ha}^{-1} \cdot \mathrm{yr}^{-1}$. However, averaged across ecosystem, extractable soil $\mathrm{K}$ changed over time in the udic $\left(1.7 \mathrm{~kg} \cdot \mathrm{ha}^{-1} \cdot \mathrm{yr}^{-1}\right)$, but did not change over time in the aquic SMR, while, averaged across SMR, extractable soil $\mathrm{K}$ did not change over time in any individual prairie ecosystem. Similarly, Brye et al. [6] reported that soil $\mathrm{K}$ in the top $10 \mathrm{~cm}$ was similar across the three youngest prairie restorations and the native prairie. However, Brye and Riley [8] reported a general increase in soil $\mathrm{K}$ as restoration age increased, as interpreted from the single soil sample in the chronosequence of prairie restorations.

Table 4. Summary of mean changes in extractable soil sulfur (S), iron (Fe), and manganese $(\mathrm{Mn})$ contents in the top $10 \mathrm{~cm}$ between soil moisture regimes over a 12 -year period averaged across an undisturbed native prairie and a chronosequence of four prairie restorations in the Ozark Highlands region of northwest Arkansas.

\begin{tabular}{ccc}
\hline \multirow{2}{*}{ Soil Chemical Property } & \multicolumn{2}{c}{ Soil Moisture Regime } \\
\cline { 2 - 3 } & Udic & Aquic \\
\hline $\mathrm{S}\left(\mathrm{kg} \cdot \mathrm{ha}^{-1} \cdot \mathrm{yr}^{-1}\right)$ & $-0.05 \mathrm{~b}^{\dagger}$ & $-0.60 \mathrm{a}^{*}$ \\
$\mathrm{Fe}\left(\mathrm{kg} \cdot \mathrm{ha}^{-1} \cdot \mathrm{yr}^{-1}\right)$ & $4.77 \mathrm{a}^{*}$ & $1.27 \mathrm{~b}$ \\
$\mathrm{Mn}\left(\mathrm{kg} \cdot \mathrm{ha}^{-1} \cdot \mathrm{yr}^{-1}\right)$ & $4.99 \mathrm{a}^{*}$ & $2.83 \mathrm{~b}^{*}$ \\
\hline
\end{tabular}

${ }^{\dagger}$ Different letters in a row are difference at $P \leq 0.05$; ${ }^{*}$ Asterisks indicate a significant change over time $(P \leq$ 0.05). 
Averaged across ecosystem and SMR, extractable soil Mg content change over time averaged $-0.6 \mathrm{~kg} \cdot \mathrm{ha}^{-1} \cdot \mathrm{yr}^{-1}$, while no individual ecosystem or SMR means changed over time. Brye et al. [6] and Brye and Riley [8] reported similar soil $\mathrm{Mn}$ contents in the three youngest restorations and a greater soil $\mathrm{Mn}$ in the oldest restoration and native prairie, while a general increase in soil Mn occurred in the three youngest restorations with increasing restoration age, as interpreted from the single soil sample in the chronosequence of prairie restorations.

Averaged across ecosystem and SMR, extractable soil Zn content change over time averaged $0.03 \mathrm{~kg} \cdot \mathrm{ha}^{-1} \cdot \mathrm{yr}^{-1}$. However, averaged across SMR, extractable soil $\mathrm{Zn}$ changed over time in the oldest restoration $\left(0.08 \mathrm{~kg} \cdot \mathrm{ha}^{-1} \cdot \mathrm{yr}^{-1}\right)$ and in the native prairie $\left(0.07 \mathrm{~kg} \cdot \mathrm{ha}^{-1} \cdot \mathrm{yr}^{-1}\right)$, while, similar to $\mathrm{K}$, averaged across ecosystem, extractable soil $\mathrm{Zn}$ changed over time in the udic $\left(0.04 \mathrm{~kg} \cdot \mathrm{ha}^{-1} \cdot \mathrm{yr}^{-1}\right)$, but did not change over time in the aquic SMR. Similarly, Brye et al. [6] and Brye and Riley [8] reported similar extractable soil $\mathrm{Zn}$ contents across all four restorations and the native prairie, as interpreted from the single soil sample in the chronosequence of prairie restorations.

Many of the inconsistent trends in soil nutrient change over time among prairie restorations may be related to differences in inherent soil properties related to parent materials and other soil-forming factors (Table 1) and differential degrees of restoration management, such as periodic mowing and prescribing burning to control invasive species. Though surface soil textures were relatively similar (Table 1), greater sub-soil variability, such as soil profile structure properties and clay contents, may influence the magnitude of soluble nutrient leaching below the top $10 \mathrm{~cm}$. Furthermore, differential vegetation establishment and functioning among the prairie restoration may also have impacted the SOM balance and resulting nutrient cycling.

Brye et al. [17] identified how important direct measurements of soil property change over time are to achieve proper interpretations of temporal changes in soil properties. In the current study, results from a single soil sampling across a chronosequence of prairie restorations [6] [8] often led to opposite interpretations or trends compared to results of direct assessments from subsequent soil sampling 12 years later. Proper interpretations of soil property change over time, particularly for extractable soil nutrients that are released from SOM decomposition, are critical for assessing prairie restoration progress and success over time. Soil nutrient changes over time integrate the behavior of SOM and contribute to the inherent soil fertility status of an ecosystem, which needs to be balanced for proper ecosystem functioning.

\section{Conclusion}

This study evaluated prairie ecosystem and SMR effects on the change in soil nutrients over a 12 -yr period across a chronosequence of four prairie restorations and a native tall grass prairie in the Ozark Highland of northwest Arkansas. In contrast to that hypothesized, results showed that the changes over time 
for most extractable soil nutrients evaluated were not greater in the younger than in the older prairie restorations, suggesting that, even after 17 years following initiation of restoration activities, a new equilibrium has not been achieved and that soil nutrient changes are still dynamic. In addition, in contrast to that hypothesized, results also demonstrated that some soil nutrients accumulated more under aquic than udic, while others accumulated more under udic than aquic soil moisture conditions. As prairie restoration activities continue in various regions, in different soils, and with varying soil surface textures, particularly in the Ozark Highlands region of northwest Arkansas, it will be increasingly important to understand how soil nutrients, released from decomposing SOM, change over time towards the likely restoration target of that which is present in a geographically relevant native prairie.

\section{Acknowledgements}

This research was partially funded by a grant from the Arkansas Natural Resources Conservation Service (Agreement Number 68-7103-17-118) and was supported by a research permit to work at the Pea Ridge National Military Park.

\section{Conflicts of Interest}

The authors declare no conflicts of interest regarding the publication of this paper.

\section{References}

[1] National Park Service (NPS) (2017) Tallgrass Prairie Conservation. National Preserve Kansas. https://www.nps.gov/tapr/index.htm

[2] Weaver, J.E. and Harmon, G.W. (1935) Quantity of Living Plant Materials in Prairie Soils in Relation to Run-Off and Soil Erosion. Papers of John E. Weaver (1884-1956). 10. http://digitalcommons.unl.edu/agronweaver/10

[3] Weaver, J.E. (1927) Some Ecological Aspects of Agriculture in the Prairie. Agronomy \& Horticulture Faculty Publications. 468. https://digitalcommons.unl.edu/agronomyfacpub/468 https://doi.org/10.2307/1929382

[4] Mlot, C. (1990) Restoring the Prairie: Big Bluestem and Other Native Tallgrass Plants Make a Comeback. Bioscience, 40, 804-809. https://doi.org/10.2307/1311481

[5] Weaver, J.E. (1968) Prairie Plants and Their Environment. Papers of John E. Weaver (1884-1956). 8. https://digitalcommons.unl.edu/agronweaver/8

[6] Brye, K.R., Riley, T.L. and Gbur, E.E. (2008) Prairie Restoration Effects on Soil Properties in the Ozark Highlands. Journal of Integrative Biosciences, 4, 87-104.

[7] McKee, M., Brye, K.R. and Wood, L. (2019) Soil Carbon Sequestration across a Chronosequence of Tallgrass Prairie Restorations in the Ozark Highlands Region of Northwest Arkansas. AIMS Geosciences, 5, 1-24. https://doi.org/10.3934/geosci.2019.1.1

[8] Brye, K.R. and Riley, T.L. (2009) Soil and Plant Property Differences across a Chronosequence of Humid-Temperate Tallgrass Prairie Restorations. Soil Science, 174, 346-357. https://doi.org/10.1097/SS.0b013e3181a93daa 
[9] Brye, K.R. and West, C.P. (2005) Grassland Management Effects on Soil Quality in the Ozark Highlands. Soil Science, 170, 63-73.

https://doi.org/10.1097/00010694-200501000-00008

[10] Brye, K.R. and Gbur, E.E. (2011) Near-Surface Soil Property Changes over Time as Effected by Grassland Management in the Ozark Highlands. Soil Science, 176, 129-135. https://doi.org/10.1097/SS.0b013e31820ca9a8

[11] United States Department of Agriculture, Soil Conservation Service (2006) Land Resource Regions and Major Land Resource Areas of the United States, the Caribbean, and the Pacific Basin. U.S. Department of Agriculture Handbook 296, Washington DC.

[12] Natural Resource Conservation Service (NRCS) (2020) Web Soil Survey. http://websoilsurvey.nrcs.usda.gov

[13] National Centers for Environmental Information (NCEI) (2010) Data Tools: 1981-2010 Normals. National Climatic Data Center. https://www.ncdc.noaa.gov/cdo-web/datatools/normals

[14] National Park Service (NPS) (2006) Final General Management Plant, Environmental Impact Statement: Pea Ridge National Military Park, Arkansas. https://play.google.com/books/reader?id=n0w3AQAAMAAJ\&pg=GBS.PP1

[15] Arkansas Natural Heritage Commission (ANHC) (2009) System of Natural Areas: Natural Areas. https://www.naturalheritage.com/Natural Areas/natural-areas-1

[16] Tucker, M.R. (1992) Determination of Phosphorus by Mehlich 3 Extraction. In: Donohue, S.J., Ed., Soil and Media Diagnostic Procedures for the Southern Region of the United States, Virginia Agricultural Experiment Station Series Bulletin 374, Blacksburg, 6-8.

[17] Brye, K.R., Cordes, F. and McKee, M. (2020) Near-Surface Soil Nutrient Changes over Time under Native Prairie and Managed Agriculture in Arkansas. Natural Resources, 11, 243-256. https://doi.org/10.4236/nr.2020.116015 